\title{
THE EFFECT OF GOOD GOVERNANCE, COMPETENCY AND FRAUD PREVENTION ON THE PERFORMANCE OF VILLAGE GOVERNMENT APPARATUS
}

\author{
Sintyah Sisca Maranda ${ }^{1}$ \\ Ni Made Dwi Ratnadi² \\ Ni Ketut Rasmini ${ }^{3}$ \\ I Dewe Gde Dharma Suputra ${ }^{4}$
}

Faculty of Economics and Business, Udayana University, Bali, Indonesia

Email: sintyamaranda1995@gmail.com

\begin{abstract}
This study aims to obtain empirical evidence regarding the effect of good governance and competence on the performance of village government officials in managing village funds with fraud prevention as moderation. This research was conducted in Kupang Regency. The number of samples taken was 115 village officials using purposive sampling method. Data was collected by distributing questionnaires. The analysis technique used is Moderated Regression Analysis (MRA). Based on the results of the analysis, it was found that good governance and competence have a positive effect on the performance of village government officials. This shows that the better the implementation of good governance and the higher the competence of the village apparatus, the higher the level of performance of the village government apparatus.
\end{abstract}

Keywords: good governance, competence, village government apparatus performance, village funds, fraud prevention

DOI: $10.7176 /$ RJFA/13-1-05

Publication date: January $31^{\text {st }} 2022$

\section{INTRODUCTION}

The performance of the village government apparatus is a measure that states how far the target has been achieved by management, where the target has been determined in advance. In accordance with Law Number 6 of 2014 concerning Villages, village government is the administration of government affairs by the village government in regulating and managing the interests of the local community based on local origins and customs that are recognized and respected in the Government System of the Unitary State of the Republic of Indonesia. Performance is the actualization between ability and motivation. Performance is the result of real achievement in a certain period both individually and in groups. Performance is evidence of success and as a benchmark for companies or organizations (Tarjo, 2020)

In order to realize good governance, the government tries to create a clean and authoritative government or what is called good governance. The implementation of good governance is an effort to implement good governance, especially in villages. As a public sector organization, village governments are required to have performance oriented to the interests of the community by trying to provide the best service. In the context of village government, the concept of good governance is used as an institutional framework to strengthen village autonomy. the implementation of village-level government autonomy will not run well if it is not supported by the application of good governance principles.

Dewi \& Gayatri (2019), Putra \& Rasmini (2019) reveal that village financial management accountability is one of the components of good governance. Accountability is very much needed as a form of accountability of the village government to the community. Accountability becomes very sensitive because it involves the obligations of the village government to the community. The community is not only given information about the existence of the village budget, but also must be given an accountability report related to the realization of the budget.

In addition to good governance, the performance of village government officials can be supported through the competence of village officials. The competence of village officials is still a problem. Increasing the competence of village officials is very important. The reason is, it is also the key to the success or failure of development in the village. The competence of the village apparatus will certainly have an impact on the effectiveness of governance in the village. Likewise, in managing village funds disbursed by the government, which continues to grow every year. The reality on the ground shows that there are many village officials whose education level is below average. In fact, some have never received an education. The majority of village officials only graduated from high school, in addition, only junior high school graduates.

The management of village funds by the village head and village officials related to the financial 
reporting system must have competent resources. These competent resources must be supported by an accounting education background, frequent training and experience in the financial sector. (Marlinawati and Wardani, 2018). In addition, the competence of skilled village apparatus is very much needed in the use of a system. Considering that villages that receive village funds are required to use the village financial system application (SISKEUDES). As a system that is packaged as an application based on an accounting information system to assist in the process of managing village funds.

Skilled village apparatus competence is very much needed in the use of siskeudes. Then the village apparatus, which in this case is the village secretary as the person in charge of managing village administration and the village treasurer as the maker of village financial report accountability, is required to be able to master accounting and computer science so that reporting accountability for village funds through the siskeudes application becomes better and more effective (Wiguna et al, 2017).

Several previous studies related to good governance conducted by Sudiarsana Putra \& Dwiana Putra (2018) showed that good governance had a positive effect on the performance of village government officials; Pratiwi \& Ulfah (2018) show that good governance has a positive effect on the performance of village government officials. The higher the implementation of good governance, the higher the managerial performance of the village government apparatus. Strengthening continuous improvement in the application of good governance in order to improve the performance of village government officials so that the goal of prospering the village community is achieved. Nurbaeti \& Nugraha (2019) shows that good governance has a positive effect on the performance of village government officials. Then the research conducted by Komarawati \&

Previous research related to competence conducted by Pratiwi \& Ulfah (2018) shows that competence has a significant effect on the performance of village government officials. In order to improve the competence of village officials, it is necessary to pay attention to an open job auction system. Marlinawati \& Wardani (2018); Sunarmo et al (2018); Tarjo (2020) shows that competence has a positive effect on the performance of village government officials.

Several studies found different results. Research conducted by Sunarmo et al shows that good governance does not have a significant effect on the performance of village government apparatus (2018); Haura et al (2019) show that good governance has no effect on the performance of village government officials. Research by Nurjaya et al (2021) shows that competence has a negative effect on the performance of village government officials.

Based on the results of previous studies, it shows that there are still inconsistencies in research results which are thought to be caused by certain factors that affect good governance and competence on the performance of village government officials. Govindarajan (1986) argues that in overcoming the inconsistency of the results of previous studies, a contingency approach is needed. Then, Ghozali (2016: 56) states that there is no unified research result due to certain factors that influence it, called contingent variables. The contingency variable used is a moderating variable, namely fraud prevention which is thought to affect the relationship between good governance and competence on the performance of village government officials.

Fraud prevention is used as a moderating variable, because fraud prevention is a system if the existing control system is very weak and there is a lack of supervision in managing village funds. Fraud can be handled in two ways, namely preventing and detecting. Fraud is a problem that must be fought for the public and private sectors. According to the RI Financial and Development Supervisory Agency (2015: 6) Several risks of fraud (fraud) that can occur in village financial management include, illegal use of village cash (theft of cash on hand), mark ups and use of village assets for the benefit of the community. village officials illegally (misuse or larceny). This of course can cause village financial losses and reduce the village government's ability to carry out its duties and functions.

\section{LITERATURE REVIEW AND HYPOTHESES DEVELOPMENT}

Stewardship Theory introduced as a theory based on behavior, human behavior (behavior), human patterns (model of man), psychological mechanisms in an organization that practice leadership as an aspect that plays an important role in achieving goals. With regard to Stewardship Theory, village officials will do the best for their organization and are responsible for what they do based on existing laws or regulations. A good organization will provide the best impact or benefit for improving its performance. Measurement of government performance is very important, because measurable performance will create public trust in the government, so that development in an area is right on target.

Good governance It is also expected to provide benefits for improving the operational capabilities of a government, improving services to stakeholders and with the right decision-making process, it is expected to be able to improve government performance. If good governance is good, it shows greater government responsibility, so that government performance will increase. 
Research conducted by Pratiwi and Ulfah (2018) shows that good governance has a positive effect on the performance of village government officials. The higher the implementation of good governance will further improve the managerial performance of the village government apparatus. The same thing was also expressed by Nurbaeti and Nugraha (2019) showing that good governance has a positive effect on the performance of village government officials. Research by Komarawati and Nugraha (2020) shows that good governance has a positive and significant effect on the performance of village government officials.

H1: Good Governance has a positive effect on the performance of village government officials.

The condition of a manager which does not prioritize individual interests, but prioritizes the goals and interests of an organization, this is described in the theory of stewardship (Davis et al, 1997). Stewardship theory suggests that a trusting relationship, an engagement-oriented environment and an empowering organizational structure will increase pro-organizational behavior and performance. The assumption of this theory is that village officials are parties with integrity, have honesty and are able to act responsibly in carrying out their actions which are shown to meet the needs of stakeholders and shareholders.

The competence of the village apparatus must be able to support the goals of the organization within the village government. The main objective of human resource management is to prepare and realize quality human resources. Competence of quality village apparatus can be seen from educational background, training that has been followed, skills expressed in carrying out tasks and job descriptions. Competence relates to the abilities that each individual must have in order to do his job well. Competence is a person's ability, so this quality is a combination of expertise (skills), knowledge (knowledge), ability (ability) to carry out work into individual characteristics to achieve maximum performance (Spencer, 1993).

Research by Sunarmo et al (2018) shows that competence has a positive and significant effect on the performance of village government officials. Research by Pratiwi and Ulfah (2018) shows that competence has a positive effect on the performance of village government officials. Research by Tarjo (2020) shows that the competence of the village apparatus has a positive effect on the performance of the village government apparatus. Research by Nurjaya et al (2021) states that competence has a positive and significant effect on the performance of village government officials. Thus, the higher the competence of the village government apparatus, the performance of the village government apparatus will increase.

$\mathrm{H} 2$ : Competence has a positive effect on the performance of village government officials.

Stewardship theory is a theory that describes a situation where stewardship (village apparatus) is more concerned with achieving an organization than individual goals or interests (Donaldson and Davis, 1989). This theory also has a psychological and sociological basis that has been designed so that a stewardship (village apparatus) is motivated to act in accordance with what the principal wants. The diamond fraud theory explains that fraud can occur when there are situations with high pressure and opportunities and are supported by individuals with low integrity. A good government requires a leader who is trustworthy, so that he can convey suggestions from the community. If good governance has been implemented properly and properly it will be able to create quality financial reports so that, can be one of the measures to prevent fraud. In addition, if an organization has implemented accountability, transparency and participation in the management of village funds, the village apparatus does not have the opportunity to commit fraud.

Research by Sarwono (2018) shows that fraud prevention has a significant effect on good governance. Research by Kurniawan and Izzaty (2019) shows that fraud prevention has a positive and significant effect on the performance of village government officials. The implementation of good governance is needed in order to prevent potential fraud that occurs in companies and public sector organizations. With the implementation of good governance will ultimately lead to organizational performance. If the implementation of good governance in the government is carried out properly, the government's performance will be better. The higher the quality of good governance implementation, the lower the potential for fraud to occur (Rowa and Arthana, 2019).

H3: Fraud prevention strengthens the influence of good governance on the performance of village government officials.

With the competence of adequate village apparatus in managing village funds, it is hoped that the economic and social objectives of the village government can be achieved. Therefore, the participation of parties outside the village government such as community leaders, religious leaders, and other community representatives must synergize and be involved in managing village funds. supervision in the management of village funds should be carried out professionally, strictly, controlled and with integrity. Research by Widiyarta et al (2018) states that the competence of village officials with poor accounting understanding causes unprofessional village fund management so that there is the potential for fraud and competence must work together in order to prevent fraud. H4: Fraud prevention strengthens the influence of competence on the performance of village government officials.

In this study, the research concept describes the relationship between good governance and competence with the performance of village government officials moderated by fraud prevention. In the relationship between good governance and competence, it is necessary to have an attitude to prevent fraud or fraud from the village 
apparatus itself to seek the performance of the village government apparatus, so that there is no form of fraud that occurs in the management of village funds. The conceptual framework of this research is presented in Figure 1.

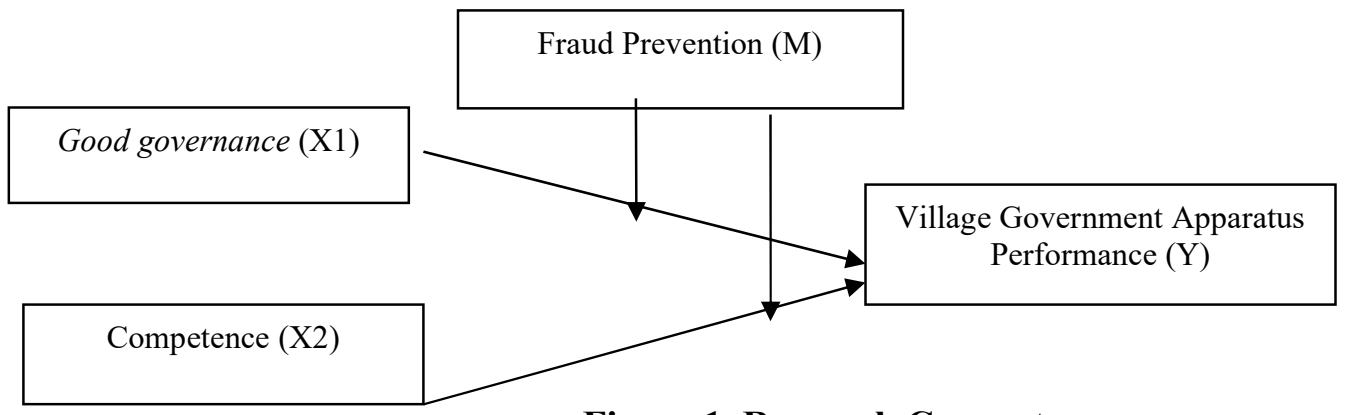

Figure 1. Research Concept

\section{RESEARCH METHODS}

The location or scope of the research area was carried out at the Community and Village Empowerment Service of Kupang Regency, East Nusa Tenggara Province. Research time for 2 (two) months. The population in this study is village government apparatus which includes the village head, village secretary and village treasurer who manages village funds in Kupang Regency, totaling 220 people spread over 160 villages. This population was chosen based on considerations because village government officials are closely related to the use or management of village funds. The sample in this study was determined using purposive sampling method. The reason for using purposive sampling technique is because not all samples have criteria that are in accordance with what the author has determined. The considerations to be used as samples in this study are,

1) Village government officials who serve as village heads, village secretaries and village treasurers who have at least served a term of office of more than 2 years. The capacity of village officials as policy implementers is an important factor that supports the successful implementation of government programs, especially in the financial sector in managing village funds.

2) Village government officials who have not completed the Accountability Report (LPJ) use village funds.

The total sample used in this study is based on the criteria of village government apparatus respondents in Kupang Regency, 122 people from 59 villages in Kupang Regency.

The data collection method is a way of collecting the data needed to answer the research problem formulation. For how to obtain data in this study by distributing questionnaires to village government officials who are directly related to the management of village funds. Dissemination of the questionnaire using google forms sent via email and whatsapp.

Hypothesis testing uses Moderated Regression Analysis (MRA) which aims to determine the effect of good governance and competence on the performance of village government apparatus and to determine the effect of fraud prevention which moderates the relationship between good governance and competence on the performance of village government apparatus. The mathematical model of the relationship between variables is as follows.

$$
\mathrm{KAPD}=+1 \mathrm{GG}+2 \mathrm{~K}+3 \mathrm{PF}+4 \mathrm{GG} * \mathrm{PF}+5 \mathrm{~K} * \mathrm{PF}+\varepsilon
$$

If the Fraud Prevention variable (M) is a moderating variable, then the coefficients 4 and 5 must be significant at (significance level).

Information:

$\mathrm{KAPD}=$ Village government apparatus performance $(\mathrm{Y})$

$\alpha \quad=$ Constant

$1-\beta 5=$ Regression Coefficient

$\mathrm{GG}=$ Good governance $(\mathrm{X} 1)$

$\mathrm{K} \quad=$ Competence $\left(\mathrm{X}_{2}\right)$

$\mathrm{PF} \quad=$ Prevention Fraud $(\mathrm{M})$

$\mathrm{GG}^{*} \mathrm{PF}=$ Interaction between Good Governance and Fraud Prevention

$\mathrm{K} * \mathrm{PF}=$ Interaction between Competence and Fraud Prevention

$\varepsilon=$ Errors/other variables not identified in the model

Based on the regression analysis, then the Goodness of Fit was observed, namely the coefficient of 
determination (R2), the feasibility test of the F model (F test) and the hypothesis test ( $\mathrm{t}$ test).

\section{RESULTS AND DISCUSSION}

\section{Descriptive Statistics}

Descriptive statistics are presented to provide information about the characteristics of the research variables, which include the minimum, maximum, average and standard deviation values. The results of the descriptive statistical test are presented in Table 1 below.

Table 1. Descriptive Statistical Results

\begin{tabular}{|c|c|c|c|c|c|}
\hline & $\mathbf{N}$ & Min & Max & mean & Std. Deviation \\
\hline Good governance (X1) & 115 & 45 & 60 & 52.48 & 5,413 \\
\hline Competence (X2) & 115 & 33 & 55 & 40,30 & 6,079 \\
\hline $\begin{array}{ll}\text { Village } & \text { Apparatus } \\
\text { Performance (Y) } & \end{array}$ & 115 & 45 & 60 & 53.45 & 5,127 \\
\hline Fraud Prevention (M) & 115 & 33 & 55 & 42.47 & 7,067 \\
\hline
\end{tabular}

Source: Secondary Data, 2021

The Good Governance variable (X1) has a minimum value of 45 and a maximum value of 60 , meaning that the average respondent's responses stated "Strongly Agree" (at the upper limit of scale 5) and "Agree" (at the lower limit of the scale 3.75) on the instrument. The research on the good governance variable and the mean value of good governance is 52.48 which means that the average value of good governance is closer to the maximum value, this means that the implementation of good governance in the village government of Kupang Regency tends to be high. The standard deviation of 5.413 means that there is a difference in good governance to the average value of 5.413 .

Competency variable (X2) has a minimum value of 33 , a maximum value of 55 , meaning that the average respondent's responses stated "Strongly Agree" (at the upper limit of scale 5) and "Neutral" (at the lower limit of scale 3 ) on the competency research instrument and the score the mean of competence is 40.30 , meaning that the average value of competence is 40.30 . The average value of competence is closer to the minimum value, this means that the competence of village government officials in Kupang Regency tends to be low. The standard deviation of 6.079 means that there is a difference in competence to the average value of 6.079 .

The Village Government Apparatus Performance Variable (Y) has a minimum value of 45, a maximum value of 60 , meaning that the average respondent's responses stated "Strongly Agree" (at the upper limit of scale 5) and "Agree (at the lower limit of the scale 3.75) on the instrument. research on the performance of the village government apparatus and the mean value of the performance of the village government apparatus of 53.45. The average value of the performance of the village government apparatus is closer to the maximum value, this means that the performance of the village government apparatus in Kupang Regency tends to be high. The standard deviation of 5.127 means that there is a difference in the performance of the village government apparatus against the average value of 5.127 .

Fraud Prevention Variable (M) has a minimum value of 33, a maximum value of 55, meaning that the average respondent's responses stated "Strongly Agree" (upper limit of scale 5) and "Neutral" (lower limit of scale 3 ) on fraud prevention research instruments and the mean fraud prevention is 42.47 . The average value of fraud prevention is closer to the minimum value, this means that fraud prevention in Kupang Regency tends to be low. The standard deviation of 7.067 means that there is a difference in fraud prevention against the average value of 7.067 .

\section{Moderated Regression Analysis (MRA)}

Moderated Regression Analysis(MRA) is a regression model by testing the interaction between variables. This hypothesis testing aims to determine the effect of good governance and competence on the performance of village government apparatus and to determine the effect of fraud prevention which moderates the relationship between 
good governance and competence on the performance of village government apparatus. The mathematical model of the relationship between variables is as follows.

$$
\mathrm{KAPD}=+1 \mathrm{GG}+2 \mathrm{~K}+3 \mathrm{PF}+4 \mathrm{GG} * \mathrm{PF}+5 \mathrm{~K} * \mathrm{PF}+\varepsilon
$$

\section{Model Feasibility Test (F Test)}

The $\mathrm{F}$ test is used to test the feasibility or validity of a regression model. The results of the $\mathrm{F}$ test can be seen in Table 2 as follows.

Table 2. Model Feasibility Test Results (Test F)

\begin{tabular}{llllll} 
Model & Sum of Squares & df & Mean Square & F & Sig. \\
\hline 1 Regression & 696,057 & 5 & 139,211 & 6.596 & $0.000 \mathrm{~b}$ \\
Residual & 2300,430 & 109 & 21,105 & & \\
Total & 2996,487 & 114 & & & \\
\hline
\end{tabular}

Source: Secondary Data, 2021

Based on Table 2 shows that the results of the ANOVA test or the F test resulted in a calculated $\mathrm{F}$ value of 6.596 with a significance level of 0.000 . Since the significant probability is much less than 0.05 , it can be said that good governance, competence and fraud prevention (moderation) together affect the performance of village government officials, so the regression model is feasible to use to predict the performance of village government officials.

\section{Coefficient of Determination Test (R2)}

The coefficient of determination test is used to measure the level of the model's ability to explain the variation of the independent variables. The results of the coefficient of determination test can be seen in Table 3 as follows.

Table 3. Coefficient of Determination Test Results (R2)

\begin{tabular}{lllll}
\hline Model & R & R Square & Adjusted R Square & Std. Error of the Estimate \\
\hline 1 & $0.482 \mathrm{a}$ & 0.232 & 0.197 & 4,594
\end{tabular}

Source: Secondary Data, 2021

Based on Table 3, the results of the coefficient of determination (R2) show that the magnitude of R2 is 0.232 , this means that 23.2 percent of the variation in the performance of the village government apparatus can be explained by variations in the independent variables of good governance, competence and fraud prevention (moderation). While the rest $(100 \%-23.2 \%=76.7 \%)$ is explained by other factors outside the model.

\section{Hypothesis Testing (Statistical t Test)}

Hypothesis testing ( $\mathrm{t}$ test) was conducted to determine the influence of the independent variable on the dependent variable individually or directly and to determine the role of the moderating variable in strengthening or weakening the independent variable on the dependent variable. The results of the hypothesis test ( $t$ test) can be seen in Table 4 below. 
Table 4. Hypothesis Test Results (t Test)

\begin{tabular}{llllll}
\hline & \multicolumn{2}{l}{ Unstandardized Coefficients } & \multicolumn{2}{c}{$\begin{array}{c}\text { Standardized } \\
\text { Coefficients }\end{array}$} \\
\cline { 2 - 4 } Model & $\mathrm{B}$ & Std. Error & Beta & $\mathrm{T}$ & Sig. \\
\hline 1 (Constant) & -89.080 & 31,643 & & $-2,815$ & 0.006 \\
Good Governance (X1) & 0.965 & 0.483 & 1.019 & 1,997 & 0.048 \\
Competence (X2) & 2,289 & 0.465 & 2,714 & 4,920 & 0.000 \\
Fraud Prevention (M) & 3,287 & 0.726 & 4,531 & 4,525 & 0.000 \\
GG*PF Interaction & -0.025 & 0.011 & -2.193 & $-2,284$ & 0.024 \\
K*PF Interaksi Interaction & -0.049 & 0.011 & $-4,022$ & -4.613 & 0.000 \\
\hline
\end{tabular}

Source: Secondary Data, 2021

\section{The Effect of Good Governance on the Performance of Village Government Apparatus}

The results of the t test show that the good governance variable (X1) has a significant effect on the performance of the village government apparatus $(\mathrm{Y})$. The good governance variable gives a parameter coefficient value of 0.0965 with a significance level of 0.048 . So that the first hypothesis (H1) is accepted. This shows that the better the implementation of good governance in the village government, the performance of the village government apparatus will increase in managing village funds.

The formulation of the first hypothesis (H1) in this study, good governance has a positive effect on the performance of village government officials. Based on the results of hypothesis testing, the statistical $t$ test $(t$ test) shows that the implementation of good governance has a positive effect on the performance of village government officials. So the first hypothesis (H1) is accepted. The purpose of this study was to determine the effect of good governance on the performance of village government officials in Kupang Regency. Good governance is one of the important factors that affect the performance of village government officials in carrying out their functions and duties. This shows that the implementation of good governance has improved the performance of the village apparatus in Kupang Regency. This is in line with the principle of transparency in the implementation of decision making and disclosing material and relevant and valid information. While budget accountability is good, automatically the information on the financial situation presented is reasonable and appropriate. With budget accountability in accordance with applicable laws and regulations, it can ensure disciplined financial management in work so that there are no illegal levies or anyone involved in KKN. The SOPs that have been set are also fully implemented in accordance with the provisions. can ensure disciplined financial management at work so that there are no illegal levies or anyone involved in KKN. The SOPs that have been set are also fully implemented in accordance with the provisions. can ensure disciplined financial management at work so that there are no illegal levies or anyone involved in KKN. The SOPs that have been set are also fully implemented in accordance with the provisions.

This is in line with the stewardship theory used, which states that village government officials as stewards will do the best for their organization and are responsible for what they do based on existing laws or regulations. A good organization will provide the best impact or benefit for improving its performance. Measurement of government performance is very important, because measurable performance will create public trust in the government, so that development in an area is right on target.

The results of this study support the research of Pratiwi \& Ulfah (2018), Sudiarsana Putra \& Dwiana Putra (2018), Nurbaeti \& Nugraha (2019) and Komarawati \& Nugraha (2020) that the application of good governance principles has a positive effect on the performance of village government officials. The higher the application of the principles of good governance, the more the managerial performance of the village government apparatus. strengthening continuous improvement in the application of the principles of good governance in order to improve the performance of the village apparatus so that the goal of the welfare of the village community is 
achieved. The results of this study mean that the better the implementation of good governance, the better the performance of village government officials in Kupang Regency.

\section{The Effect of Competence on the Performance of Village Government Apparatus}

The competency variable (X2) has a significant effect on the performance of the village government apparatus (Y). The competency variable provides a parameter coefficient value of 2.289 with a significance level of 0.000 . So the second hypothesis (H2) is accepted. This shows that the higher the competence of the village apparatus, the performance of the village government apparatus will increase in managing village funds.

The formulation of the second hypothesis $(\mathrm{H} 2)$ in this study competence has a positive effect on the performance of village government officials. Based on the results of hypothesis testing by statistical $t$ test $(t$ test). This shows that competence has a positive effect on the performance of village government officials. So the second hypothesis (H2) is accepted. This shows that the increasing competence of the village government apparatus will also increase the managerial performance of the village government apparatus. In general, although the competence of the village apparatus in Kupang Regency has an average high school education, the village apparatus has received sufficient training so that they can increase their role in society. Based on the responses of research respondents, it can be concluded that the village apparatus already has good competence.

This is in line with the stewadship theory which shows that a trusting relationship, an engagementoriented environment and an empowering organizational structure will improve pro-organizational behavior and performance. The assumption of this theory is that the village apparatus is a party with integrity, upholds honesty and is able to act responsibly in carrying out its actions aimed at meeting the needs of stakeholders and shareholders. To be able to produce good and quality performance, adequate competence of resources is needed to be able to run the system properly. Competency development of village government apparatus can be done by increasing their educational background or participating in education and training organized by the government (central/provincial/district/city).

The results of this study support the research of Sunarmo et al (2018) that competence has a positive and significant effect on the managerial performance of village government officials. this is because the competence of human resources is a determinant of organizational success, if an organization has a competent apparatus, the performance of the organization will increase. Pratiwi and Ulfah (2018) human resource competence has a positive effect on the performance of village government officials. The higher the competence of human resources will increase the managerial performance of the village government apparatus. In order to improve the competence of human resources, it is necessary to pay attention to an open job auction system and the application of a reward system.

Tarjo (2020) human resource competence has a positive and significant effect on the performance of village government officials, meaning that human resource competence greatly determines the success of a job. The performance of the village apparatus can be in the form of quality in making reports, timely reporting and also quality in managing all the work that is the responsibility. Given the authority, the village must be able to properly manage their respective tasks, so its success is determined by the ability of the apparatus itself. The results of this study indicate that the better the competence of the village apparatus, the better the performance of the village government apparatus of Kupang Regency.

\section{Fraud Prevention Moderates the Effect of Good Governance on Village Government Apparatus Performance}

The coefficient of interaction of good governance with fraud prevention variable (GG*PF) has a negative coefficient of -0.025 which can be interpreted, that with increasing fraud prevention, the influence of good governance on the performance of village government officials decreases. In other words, fraud prevention weakens the influence of good governance on the performance of village government officials. So the third hypothesis (H3) is rejected. The formulation of the third hypothesis (H3) in this study of fraud prevention strengthens the influence of good governance on the performance of village government officials. Based on the results of hypothesis testing statistically (t-test) shows that fraud prevention weakens the influence of good governance on the performance of village government officials. So the third hypothesis $(\mathrm{H} 3)$ is rejected.

The results of research on fraud prevention as a moderating variable of the relationship between good governance and the performance of village government apparatus show that fraud prevention weakens the relationship between good governance and the performance of village government apparatus. The results of the study indicate that the implementation of good governance is one of the important things in preventing fraud in the organization. One of the principles of government administration in Law Number 32 of 2004 concerning 
Regional Government is the principle of public interest rather than personal interest. This is in accordance with the stewardship theory where a leader must be able to prioritize the public interest over personal interests, besides that the village apparatus must have a trustworthy nature that can convey suggestions and input from the principal or the community.

The results of this study are in line with research by Sarwono (2018) which shows that prevention fraudsignificant effect on good governance. Research by Kurniawan \& Izzaty (2019) shows that fraud prevention has a positive and significant effect on the performance of village government officials. Implementation of good governance is needed in order to prevent potential fraud that occurs in companies and organizations. Rowa \& Arthana Research (2019) If the implementation of good governance in the government is carried out well, the government's performance will be better. The higher the quality of the implementation of good governance, the lower the potential for fraud to occur.

\section{Fraud Prevention Moderates the Effect of Competence on the Performance of Village Government} Apparatus

The coefficient of interaction of competence with fraud prevention variable $(\mathrm{K} * \mathrm{PF})$ has a negative coefficient of -0.049 which can be interpreted, that with increasing fraud prevention, the influence of competence on the performance of village government officials decreases. In other words, fraud prevention weakens the influence of competence on the performance of village government officials. So the fourth hypothesis (H4) is rejected. The formulation of the fourth hypothesis (H4) in this study of fraud prevention strengthens the influence of competence on the performance of village government officials. Based on the results of hypothesis testing statistically (t-test) shows that fraud prevention weakens the influence of competence on the performance of village government officials. So the fourth hypothesis (H4) is rejected.

The management of village funds must have good human resource competence, which means the abilities that the village apparatus must possess in the form of knowledge, skills, attitudes, and behaviors needed in carrying out their duties. This needs to be done in addition to good village financial management. It can also be used for village governance and able to coexist and avoid information asymmetry. Village funds are funds provided by the central government that require professionalism in their management, so that they are right on target and do not violate predetermined rules and are adjusted to the interests of the village government in synergy with the community to achieve optimal village income with the aim of prospering the village community.

Adequate competence of the village apparatus both in terms of quantity and quality will increase the accountability of village budget realization reports, so that all responsibilities can be carried out properly and avoid all acts of fraud. The results of this study are in line with the research of Atmaja \& Saputra (2017) which in essence states that the competence of the apparatus has a significant positive influence on the fraud prevention process in managing village funds.

\section{CONCLUSION}

Good governancehas a positive effect on the performance of village government officials in managing village funds. This shows that the better the implementation of good governance in Kupang Regency, the performance of village government apparatus in Kupang Regency is increasing.

Competence has a positive effect on the performance of village government officials. This shows that the better the competence of the village apparatus in Kupang Regency, the better the performance of the village government apparatus in Kupang Regency.

Fraud prevention is able to moderate the relationship between good governance and the performance of village government apparatus, indicating that fraud prevention weakens the relationship between good governance and the performance of village government apparatus. The ability of the village apparatus has an important role in managing village funds to achieve a common goal, namely by improving the welfare of the community through improving the village economy, social, culture and other fields. use and management of village funds and be able to account for. Fraud prevention will increase if it is supported by good governance so as to improve the performance of village government officials in managing village funds. This indicates that the implementation of good governance is one of the important things in preventing fraud in the organization. If the implementation of good governance in the village government apparatus is carried out properly, the performance of the village apparatus will be better. The higher the quality of the implementation of good governance, the lower the potential for fraud to occur. 
Fraud prevention is able to moderate the relationship between competence and the performance of village government apparatus, indicating that fraud prevention weakens the relationship between competence and performance of village government apparatus. Management of village funds, must have good village apparatus competence, which means the abilities that must be possessed by village officials in the form of knowledge, skills, attitudes, and behaviors needed in carrying out their duties. This needs to be done in addition to good village financial management, it can also be for village governance. Adequate competence of the village apparatus both in terms of quantity and quality will increase the accountability of village budget realization reports, so that all responsibilities can be carried out properly and avoid all acts of fraud.

To maximize fraud prevention actions among village officials, the Government can divide tasks according to educational background and ensure that there is no overlap in the division of tasks, and the government can provide training on how to make good and appropriate financial reports in order to minimize errors in reporting. .

\section{REFERENCE}

Atmaja, A.T \& Saputra, K.A.K. (2017). Pencegahan Fraud Dalam Pengelolaan Keuangan Desa. Jurnal Ilmiah Akuntansi dan Bisnis. https://doi.org/10.24843/jiab.2017.v12.i01.p02

Buku Pintar Dana Desa Untuk Kesejahteraan Rakyat 2019

Dharmawan T \& Supriatna, N. (2016). Pengaruh Implementasi Sistem Pengendalian Internal Terhadap Kinerja Instansi Pemerintah (Studi Kasus Pada Organisasi Perangkat Daerah Pemerintah Kota Bandung. Jurnal Riset Akuntansi dan Keuangan. https://doi.org/10.17509/jrak.v4i1.7716

Dewi, N.K.A.J.P. \& Gayatri (2019). Faktor-Faktor yang Berpengaruh Pada Akuntabilitas Pengelolaan Dana Desa. E-Jurnal Akuntansi Universitas Udayana.Vol.26.2.February.https://doi.org/10.24843/EJA.2019.v26.i02.p1

Donaldson, L., \& Davis, J. H. 1991. Stewardship theory or agency theory: CEO governance and shareholder returns. Australian Journal of Management, 16: 49-64.

Hofrichter, D.A., \& Jr Spencer, L.M. (1996). Competencies: The Right Foundation for Effective Human Resources Management. Compensation and Benefits Review, 28(6), 21-24

Hidayati, F.K. \& Widiastuti, H. (2018). Pengaruh Pengendalian Internal dan Good Goverment Governance Terhadap Tindak Pencegahan Kecurangan. Seminar Nasional dan The 6th Call for Syariah Paper. Universitas Muhamadyah Surakarta.

Kurniawan, P.C \& Izzaty, K.N. (2019). Pengaruh Good Corporate Governance dan Pengendalian Internal Terhadap Pencegahan Fraud". Journal of Economics and Banking. https://doi.org/10.35829/econbank.v1i1.2

Komarawati, T.W \& Nugraha, D.S. (2020). Pengaruh Good Governance, Sistem Pengendalian Intern Pemerintah dan Komitmen Organisasi Terhadap Kinerja Aparatur Pemerintah Daerah Seta Implikasinya Pada Pelayanan Publik Pemerintah Kabupaten Bandung Barat. Prosiding Industrial Research Workshop and National Seminar Bandung 26-27 Agustus 2020.

Laksmi, P.S.P., \& Sujana, I.K. (2019). Pengaruh Kompetensi SDM, Moralitas dan Sistem Pengendalian Internal terhadap Pencegahan Fraud dalam Pengelolaan Keuangan Desa. E-Jurnal Akuntansi Universitas Udayana. Vol.26 (3). 2155-2182. https://doi.org/10.24843/EJA.2019.v26.i03.p18

Madhu, P. (2012). What is Good Governance.SSRN Electronic Journal. https://doi.org/10.2139/ssrn.1766267

Mahsun, Moh. (2018). Akuntansi Sektor Publik (Edisi Keitga). Yogyakarta: BPFE.

Nurjaya.,Azhar Affandy., Dodi Ilham., Jasmani., \& Denok Sunarsi. (2021). Pengaruh Kompetensi Sumber Daya Manusia dan Kemampuan Pemanfaatan Teknologi Terhadap Kinerja Aparatur Desa Pada Kantor Kepala Desa di Kabupaten Gunung Kidul. Jurnal Ilmiah Manajemen Sumber Daya Manusia. Vol.4 (3). 332-346. p-ISSN: 2581-2769. e-ISSN:2598-9502.

Nurhazizal, M.,Yesi Muthia Basri., \& Azwir Nasir. (2019). Pengaruh Komitmen Organisasi, Gaya Kepemimpinan dan Kompetensi SDM Terhadap Kinerja Pemerintah Desa: Good Governance Sebagai Pemediasi. Jurnal Akuntansi. Vol. 8(1). 80-92. ISSN: 2337-4314.

Nurbaeti, T \& Nugraha, D.S. (2019). Pengaruh Good Governance dan Sistem Pengendalian Interen Pemerintah Terhadap Kinerja Aparatur Pemerintah Daerah dan Implikasinya Pada Pelayanan Publik Pemerintahan Kabupaten Garut. Industrial Research Workshop and National Seminar.

Putra, I.M.Y.D \& Rasmini,N.K.(2019). Pengaruh Akuntabilitas, Transparansi, dan Partisipasi Masyarakat Pada Efektivitas Pengelolaan Dana Desa. E-Jurnal Akuntansi. https://doi.org/10.24843/EJA.2019.v28.i01.p06

Pratiwi, U \& Ulfah P. (2018). Faktor yang Mempengaruhi Kinerja Aparatur Pemerintah Desa dalam Akuntabilitas Dana Desa. Jurnal Riset Akuntansi dan Keuangan. http://ejournal.upi.edu/index.php/JRAK

Putra, I.G.A.S., \& Dwiana Putra, I.M.P. (2018). Pengaruh Good Governance dan Sistem Pengendalian Intern 
Pemerintah Pada Kinerja Pemerintah Daerah. E- Jurnal Akuntansi. https://doi.org/10.24843/eja.2018.v25.i03.p04

Raharjo, M.M. (2020). Pengelolaan Keuangan Desa dan Aset Desa. Jakarta: Penerbit Bumi Aksara

Rowa, C.W.F., \& Arthana, I.K. (2019). Pengaruh Good Corporate Governance Terhadap Pencegahan Fraud Pada Bank Prekreditan Rakyat di Kota Kupang Jurnal Akuntansi Transparansi Akuntabilitas. https://doi.org/10.35508/jak.v7i2.1702

Spencer, M.L.,\& Spencer, M.S.(1993). Competence at Work Modelas for Superrior Performance, Jhon Willy \& Son, Inc: New York, USA

Singleton \& Singleton. (2010). Fraud Auditing and Forensic Accounting Fourth Edition. Wiley Corporate F\&A Sugiyono. (2018). Metode Penelitian Bisnis Kuantitatif, Kualitatif, dan R\&D. Bandung: PT. Alfabeta Cipta.

Saputra, K.A.K., Pradnyanitasari, P.D., \& Priliandani, N.M.I. (2019). Praktek Akuntabilitas dan Kompetensi Sumber Daya Manusia untuk Pencegahan Fraud dalam Pengelolaan Dana Desa. Jurnal Riset Akuntansi. https://ejournal.warmadewa.ac.id

Sunarmo, A.S., Widianingsih, R.W.,Pratiwi, U.P.,\& Hidayat, T.H. (2018). Penerapan Prinsip-Prinsip Good Goverment Governance, Sistem Pengendalian Intern Pemerintah, dan Kompetensi SDM Terhadap Kinerja Aparatur Pemerintah Daerah. Jurnal Analisis Bisnis Ekonomi. https://doi.org/10.31603/bisnisekonomi.v16i1.2126

Supriatna, N. (2016). Pengaruh Implementasi Sistem Pengendalian Internal Terhadap Kinerja Instansi Pemerintah (Studi Kasus Pada Organisasi Perangkat Daerah Pemerintah Kota Bandung. Jurnal Riset Akuntansi dan Keuangan. https://doi.org/10.17509/jrak.v4i1.7716

Tarjo. (2020). Pengaruh Kompetensi Sumber Daya Manusia dan Pemanfaatan Teknologi Informasi Terhadap Kinerja Aparatur Desa. Jurnal Manajemen. Vol 12(2), 334-340. http://journal.feb.unmul.ac.id

Peraturan Pemerintah Republik Indonesia Nomor 60 Tahun 2014 tentang Dana Desa yang Bersumber dari Anggaran Pendapatan dan Belanja Negara. (2014). Indonesia.

Peraturan Menteri Dalam Negeri Republik Indonesia Nomor 113 Tahun 2014 tentang Pengelolaan Keuangan Desa. (2014). Indonesia.

Peraturan Pemerintah Pengganti Undang-Undang Republik Indonesia Nomor 1 Tahun 2020 tentang Kebijakan Keuangan Negara dan Stabilitas Sistem Keuangan untuk Penanganan Pandemi Covid-19 Dalam Rangka menghadapi ancaman yang membahayakan Perekonomian Nasional. (2020). Indonesia.

Peraturan Menteri Desa, Pembangunan Daerah Tertinggal, Dan Transmigrasi Republik Indonesia Nomor 6 Tahun 2020 tentang Perubahan atas Peraturan Menteri Desa, Pembangunan Daerah Tertinggal, dan Transmigrasi Nomor 11 Tahun 2019 tentang Prioritas Penggunaan Dana Desa Tahun 2020. (2020). Indonesia.

Peraturan Menteri Desa, Pembangunan Daerah Tertinggal dan Transmigrasi Republik Indonesia Nomor 7 Tahun 2020 tentang Perubahan Kedua atas Peraturan Menteri Desa, Pembangunan Daerah Tertinggal dan Transmigrasi Nomor 11 Tahun 2019 tentang Prioritas Penggunaan Dana Desa Tahun 2020. (2020). Indonesia.

Peraturan Menteri Desa, Pembangunan Daerah Tertinggal Dan Transmigrasi Republik Indonesia Nomor 13 Tahun 2020 tentang Prioritas Penggunaan Dana Desa Tahun 2020.(2020). Indonesia.

Undang-Undang Nomor 6 Tahun 2014 tentang Desa.(2014). Indonesia. 